\title{
Filosofia della mente e recenti elaborazioni della fisica contemporanea
}

\section{Paolo Di Sia ${ }^{1-3}$}

${ }^{1}$ Scuola di Scienze \& Dipartimento di Neuroscience, Università di Padova, Via Jappelli 1, 35121 Padova, Italia

${ }^{2}$ Facoltà di Scienze e Tecnologie, Libera Università di Bolzano, Piazza Università 5, 39100 Bolzano, Italia

3E-mail:paolo.disia@gmail.com

\section{Riassunto}

La metafisica studia l'essenza delle entità, lasciando alle scienze particolari lo studio degli aspetti empirici, specifici, mutevoli ed instabili. In questo senso essa è vicina all'ontologia, in relazione a problemi come l'esistenza di Dio, l'essere “in sè", l'immortalità della coscienza, l'origine e il significato dell'universo. Anche la fisica speculativa spinge il suo interesse verso le questioni metafisiche, a livello tecnico (matematico) e a livello di pensiero (in relazione alla filosofia). Negli ultimi anni la fisica speculativa ha studiato e sviluppato interessanti concetti e idee, che coinvolgono le ultime teorie quantistico-relativistiche unificate. La ricerca di un significato della vita trova fermento nella ricerca di un significato circa l'esistenza del nostro universo, anche come possibile parte di un multiverso che lo contiene.

$\mathrm{Ci}$ sono aspetti controversi sul ruolo della coscienza nel processo di riduzione della funzione d'onda in meccanica quantistica; ciò restringe il campo di validità di alcuni principi fondamentali durante l'interazione tra microsistemi e macrosistemi, con conseguente diversificazione della definizione dello stato ontologico di coscienza e realtà.

Dalle risposte di Wittgenstein ai paradossi della comunicazione e del relativismo concettuale emerge una tensione nella sua visione dei giochi linguistici e nei suoi esperimenti mentali, che può essere meglio compresa attraverso alcune riflessioni di Wittgenstein su Einstein e la sua teoria della relatività. 
Parole chiave: Filosofia della mente, Fisica contemporanea, Metafisica, Coscienza, Ontologia, Uni-Multiverso, Significato.

\section{Bibliografia}

[1] P. Di Sia, Approaching youngs to unified theories: the charm of string theories, Procedia Social and Behavioral Sciences Journal (Elsevier), 174C, 10-16 (2015).

[2] P. Di Sia, Fine-Tuning, Universo, Multiverso tra Scienza, Filosofia e Teismo, Roma: Aracne Editrice (in press) (2019).

[3] R. T. Cahill, C. M. Klinger, Pregeometric modeling of the spacetime phenomenology, Physics Letters A, 223 (5), 313-319 (1996).

[4] P. Di Sia, About the existence of the universe among speculative physics, metaphysics and theism: an interesting overview, International Letters of Social and Humanistic Sciences (ILSHS), 9(1), 36-43 (2015).

[5] P. Di Sia, Exciting Peculiarities of the Extreme Physics, Journal of Physics: Conference Series, 442 (1), 012068 (6 pp.) (2013).

[6] P. Di Sia, Spacetime unified current models and deterministic computation, Journal of Science, 5(2), 65-67 (2015).

[7] P. Di Sia, Spazi di Calabi-Yau e teorie di stringa, Periodico di Matematiche, VIII, 6(3), 49-59 (2006).

[8] S.-T. Yau, S. Nadis, The Shape of Inner Space: String Theory and the Geometry of the Universe's Hidden Dimensions, New York: Basic Books (Reprint ed.) (2012).

[9] P. Di Sia, About the peculiar Aspects of Relativity and beyond: a pedagogical Perspective, American Journal of Educational Research, 2(6), 357-360 (2014), doi: 10.12691/education-2-6-4. [10] N. Bostrom, Are You Living In a Computer Simulation?, Philosophical Quarterly, 53(211), 243-255 (2003).

[11] L. Susskind, J. Lindesay, An Introduction To Black Holes, Information And The String Theory Revolution - The Holographic Universe, Singapore: World Scientific Pub Co Inc (2004). [12] R. Lanza, B. Berman, Biocentrism: How Life and Consciousness Are the Keys to Understanding the True Nature of the Universe, Dallas: Benbella Books (2010).

[13] P. Di Sia, Looking at the Dimension of Time among Science, Psychology and Everyday Reality, International Letters of Social and Humanistic Sciences (ILSHS), 1(2), 146-153 (2015). 
[14] L. M. Surhone, M. T. Timpledon, S. F. Marseken (Eds), Chaotic Inflation Theory: Inflation (Cosmology), Big Bang, Chaos Theory, Observable Universe, False Vacuum, Steady State Theory, Mauritius: Betascript Publishing (2010).

[15] D. Wallace, The Emergent Multiverse: Quantum Theory according to the Everett Interpretation, Oxford: Oxford University Press (Reprint ed.) (2014).

[16] K. J. Kraay, The Theistic Multiverse: Problems and Prospects, in: Y. Nagasawa (Ed.), Scientific Approaches to the Philosophy of Religion, Houndsmills: Palgrave MacMillan (2012).

[17] P. Di Sia, On Quantum Physics, Metaphysics and Theism, in: Relations. Ontology and Philosophy of Religion, Sesto San Giovanni: Mimesis International (2018).

[18] N. Bohr, Can quantum-mechanical description of physical reality be considered complete?, The Physical Review, 48, 696-702 (1935).

[19] J. von Neumann, Mathematical Foundations of Quantum Mechanics, Princeton: Princeton University Press (Reprint ed.) (1996).

[20] E. P. Wigner, Remarks on the mind-body question, in: John Heil (Ed.), Philosophy of Mind: A Guide and Anthology, Oxford: Oxford University Press (2003).

[21] D. Albert, B. Loewer, Interpreting the many worlds interpretation, Synthese, 86, 87-98 (1988).

[22] D. Bohm, A suggested interpretation of the quantum theory in terms of Hidden Variables I and II, The Physical Review, 48, 166-179, 180-193 (1952).

[23] H. Everett, Relative state formulation of quantum mechanics, Review of modern physics, 29, 454-462 (1957).

[24] G. C. Ghirardi, A. Rimini, T. Weber, Unified dynamics for microscopic and macroscopic systems, The Physical Review D, A42, 470-491 (1986).

[25] M. Gell-Mann, J. B. Hartle, Quantum mechanics in the light of cosmology, in: 3rd International symposium on the foundations of quantum mechanics in the light of new technology, Tokyo, Physical Society of Japan (1989).

[26] W. H. Zurek, Decoherence and the transition from quantum to classical, Physics Today, 3644 (1991).

[27] C. Penco, Matematica e gioco linguistico, Wittgenstein e la filosofia della matematica del ‘900, Firenze: Le Monnier (1981). 
[28] C. Penco, Wittgenstein, Locality and Rules, Wittgenstein Today, 249-74 (2004).

[29] G. E. M. Anscombe, Introduzione al 'Tractatus' di Wittgenstein, Roma: Ubaldini (1966).

[30] R. J. Fogelin, Wittgenstein, London-New York: Routledge \& Kegan Paul (1976).

[31] E. Grimi, G. E. M. Anscombe. The Dragon Lady (con testimonianze inedite), Siena: Cantagalli (2014).

[32] R. Monk, Ludwig Wittgenstein: The Duty of Genius, New York: Penguin Books $(1990 / 1991)$.

[33] Pagina consultata (12-09-2019): http://gf2045.com/.

[34] R. Kurzweil, The Singularity is Near: When Humans Transcend Biology, New York: Viking Press (2005).

[35] P. Di Sia, Relativistic nano-transport and artificial neural networks: details by a new analytical model, International Journal of Artificial Intelligence and Mechatronics (IJAIM), 3(3), 96-100 (2014).

[36] M. A. Lebedev, M. A. L. Nicolelis, Brain-machine interfaces: past, present and future, TRENDS in Neurosciences, 29(9), 536-546 (2006).

[37] J. Blascovich, J. Bailenson, Infinite Reality, New York: HarperCollins Publishers (2011).

[38] P. Di Sia, Looking at the Quantum Internet, International Academic Journal E-methodology, 4, 31-35 (2017), doi: 10.15503/emet2017.31.35.

[39] N. Kumar Bhadra, P. Di Sia, MIND AND CONSCIOUSNESS AS CREATED BY ELECTROMAGNETIC FORCE, International Journal of Applied and Advanced Scientific Research (IJAASR), 4(1), 1-6 (2019), doi: http://doi.org/10.5281/zenodo.2573101.

[40] J. S. Bell, Speakable and unspeakable in Quantum Mechanics, Cambridge: Cambridge University Press (1987).

[41] L. Nichol (Ed.), The Essential David Bohm, London: Routledge (2002).

[42] P. Di Sia, FISICA MODERNA, COSCIENZA, MULTIVERSO, AZIONE DIVINA Problemi, dubbi, convergenze, Roma: Stamen (2018). 